\title{
Prolongation of rat pancreatic islet allograft survival by treatment of recipient rats with monoclonal anti-interleukin-2 receptor antibody and cyclosporin
}

\author{
H.J.Hahn' ${ }^{1}$, B. Kuttler ${ }^{1}$, A. Dunger ${ }^{1}$, I. Klöting ${ }^{1}$, S. Lucke ${ }^{1}$, H. D. Volk ${ }^{2}$, R. v. Baehr ${ }^{2}$ and T. Diamantstein ${ }^{3}$ \\ ${ }^{1}$ Central Institute of Diabetes "G. Katsch" Karlsburg, and \\ ${ }^{2}$ Institute of Medical Immunology, Humboldt-University, Berlin, GDR; \\ ${ }^{3}$ Immunology Research Unit, Klinikum Steglitz, Free University, Berlin (West)
}

\begin{abstract}
Summary. Since interleukin-2-receptor expressing cells play a role in allograft rejection, we investigated the effect of anti-interleukin-2 receptor monoclonal antibody treatment on graft survival of allografted pancreatic islets. When pancreatic islets obtained from Lewis A-rats (haplotype RT1 $1^{\mathrm{a}}$ ) were grafted under the kidney capsules of streptozotocin-diabetic Lewis rats (haplotype $R T 1^{\mathrm{u}}$ ), the recipients relapsed into hyperglycaemia within 11 days ( $7 \pm 1$ days). Treatment of the recipient rats with low-dose cyclosporin $(1.5 \mathrm{mg} / \mathrm{kg}$ body weight) had no effect on allograft survival ( $9 \pm 1$ days). The application of anti-interleukin-2 receptor monoclonal antibody $(1 \mathrm{mg} / \mathrm{kg}$ body weight) for 10 days resulted in a prolongation of allo-
\end{abstract}

graft survival $(42.5 \pm 15.3, p<0.01)$. In 3 out of 11 animals a permanent normoglycaemia ( $>120$ days) associated with glucose intolerance was observed. When the recipients were treated for 10 days with cyclosporin and anti-interleukin-2 receptor monoclonal antibody, the allograft survival was also prolonged $(45.1 \pm 14.6, p<0.01)$; again 3 out of 11 animals remained permanently normoglycaemic while exhibiting a normal glucose tolerance.

Keywords: Pancreatic islet allograft, immunotherapy, anti-IL-2 RMAB, cyclosporin, graft histology.
Prevention and treatment of allograft rejection remain the major problems in clinical organ transplantation. It is generally accepted that sensitized $\mathrm{T}$ lymphocytes play a pivotal role in allograft rejection. Sensitized T cells express transiently the receptor for interleukin 2 (IL-2), the major cytotrophic factor for immunocompetent $T$ lymphocytes [1]. The interaction of IL-2 with receptor bearing cells is a prerequisite for clonal expression and continued viability of activated $\mathrm{T}$ cells. Because all proliferating T lymphocytes express IL-2 receptors, a receptor-targeted therapy should create a selective immune defect in the recipient [1]. Very recently Lord et al. [2] demonstrated the existence of IL-2 receptor bearing cells in infiltrated cardiac allografts during rejection. Recipients' treatment with IL-2 receptor antibodies leads to a prolongation of allografted hearts [3].

In this study we investigated the application of a mouse monoclonal antibody on allogeneic rejection in rat pancreatic islet transplantation. The monoclonal antibody used (ART18 mab) reacts with the rat lymphoblasts, identifies the rat IL-2 receptor and inhibits binding of IL-2 to IL-2 receptor (IL-2R) positive cells as well as IL-2 dependent proliferation of IL-2R bearing cells $[1,4]$.

\section{Materials and methods}

\section{Animals}

Female Lewis rats (LEW.1W MaxK, haplotype RT1 ${ }^{\text {u }}$ ) with a body weight of $180 \mathrm{~g}$, made diabetic by application of streptozotocin ( $50 \mathrm{mg} / \mathrm{kg}$ body weight, Upjohn Company Kalamazoo, Mich, USA), served as recipients. About 10 days after induction of hyperglycaemia the rats were anaesthesized, the abdominal cavity opened and the pancreas biopsied to measure pancreatic insulin content [5]. One thousand isolated islets obtained from LEW.1A MaxK rats (haplotype RT1 ${ }^{\mathrm{a}}$ ) were grafted under the right kidney capsules.

Body weight and plasma glucose were measured daily for the first 3 weeks, then 3 times weekly up to week 7 and weekly up to week 17 . Graft rejection was established when a glucose concentration above $9.5 \mathrm{mmol} / \mathrm{l}(+2 \mathrm{SD}$ above normal range of LEW.1W MaxK rats) was determined by 2 consecutive measurements within 3 days.

The hyperglycaemic animals were killed 1 week after rejection, the kidney removed for morphological investigation and the pancreatic insulin content measured [5]. In normoglycaemic rats, an intraperitoneal glucose tolerance test was performed 40 and 120 days after transplantation. One day later a pancreatic biopsy was taken to repeat the determination of pancreatic insulin content [5]. During the last operation the right kidney was removed for histological investigation. After graft removal, plasma glucose was measured daily for 4 days.

\section{Islet isolation and graft characterisation}

Pancreatic islets were prepared from 8- to 12-day-old LEW.1A MaxK rats using a fractionated collagenase digestion. About 1050 freshly 


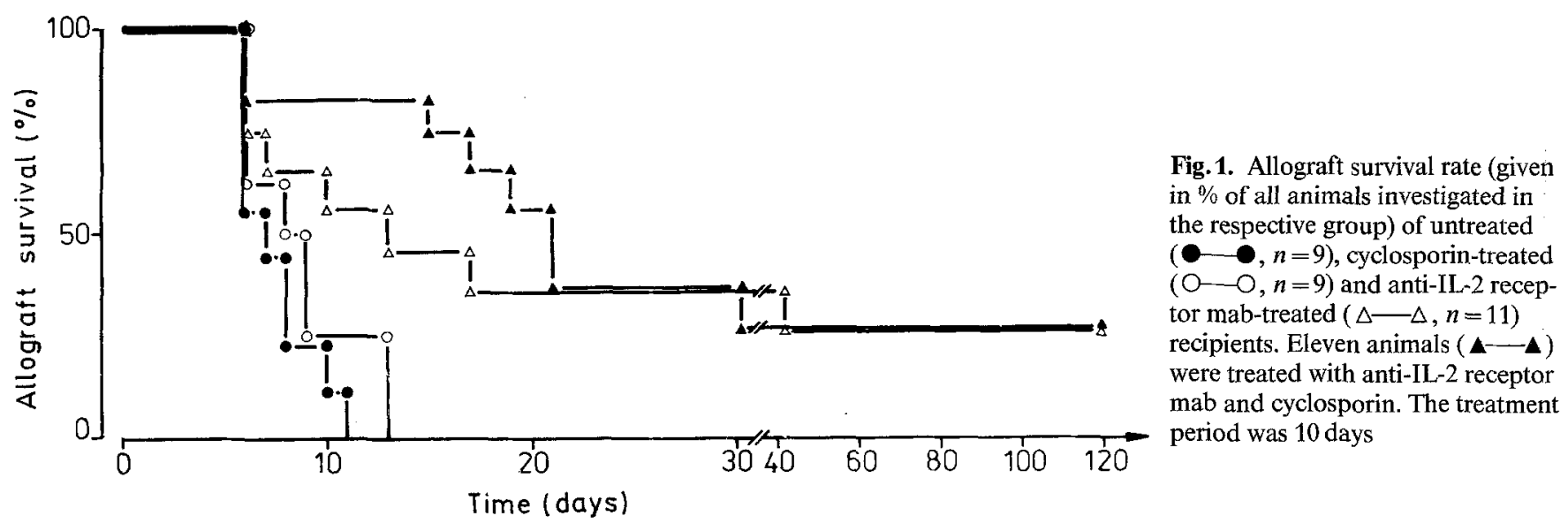

isolated islets were collected, and 50 islets were taken for graft characterization. Islet insulin content was measured after ultrasonic homogenization in triplicates ( 3 times 5 islets) [6]. After a preincubation period of $30 \mathrm{~min}, 10$ islets were incubated for $120 \mathrm{~min}$ in a modified Krebs-Ringer bicarbonate buffer at $37^{\circ} \mathrm{C}$ in an atmosphere of $95 \% \mathrm{O}_{2}$ and $5 \% \mathrm{CO}_{2}(\mathrm{pH} 7.4)$ in the presence of 1.5 or $20.0 \mathrm{mmol} / \mathrm{I}$ glucose [6].

\section{Immunotherapy}

The grafted animals were either used as untreated control rats (group 1, n=9) or treated daily with cyclosporin (group $2,1.5 \mathrm{mg} / \mathrm{kg}$ body weight intramuscularly for 10 days, $n=9$, Sandoz AG, Basel, Switzerland), or anti-IL-2 RMAB (group $3,1 \mathrm{mg} / \mathrm{kg}$ body weight intraperitoneally for 10 days, $n=11$ ). Finally, a group of animals (group 4, $n=11$ ) was treated for 10 days with cyclosporin and anti-IL-2 RMAB. The production and biological characterization of the anti-interleukin-2-receptor monoclonal antibody (anti-IL-2Rmab) used has been published elsewhere $[1,4]$.

\section{Morphology}

The removed kidneys were fixed in Bouin's solution, embedded in paraffin and cut in $7 \mu \mathrm{m}$ serial sections, which were either stained with haematoxylin-eosin or immunostained for insulin using a monoclonal anti-insulin antibody (IAK-36a C10 mab) and fluorescein-isothiocyanat-labelled anti-mouse immunoglobulins (Staatliches Institut für Immunpräparate und Nährmedien, Berlin, GDR) [7].

\section{Analytical methods}

Plasma glucose taken from the tail vein was measured by using a Beckman glucose analyzer (Beckman Instruments, Fullerton, Calif, USA). To assess the animals' glucose tolerance, $2.0 \mathrm{~g}$ glucose were applied per kilogramme body weight intraperitoneally, and plasma glucose was determined at $0,10,30,60$ and $120 \mathrm{~min}$. The insulin concentrations in tissue and buffer were measured by radioimmunoassay.

\section{Statistical analysis}

The results were calculated as mean \pm SEM of $n$ different animals. Statistical significance was evaluated by Student's t-test or by the Wilcoxon or Mann and Whitney's U-test (graft survial). A $p$ value of $<0.01$ was considered statistically significant. The glucose tolerance is given as integrated area under the glucose curve during the test period of $120 \mathrm{~min}$. The graft survival is given in percent of the total group of animals transplanted.

\section{Results}

At the time of transplantation the grafted animals had a marked hyperglycaemia, which did not differ between the groups (ranging between $28.6 \pm 1.8 \mathrm{mmol} / \mathrm{l}$ (group 4) and $29.7 \pm 1.2 \mathrm{mmol} / \mathrm{l}$ (group 3)), and a markedly reduced pancreatic insulin content (ranging between $0.73 \pm 0.14 \mathrm{pmol} / \mathrm{mg}$ wet weight (group 4) and $1.38 \pm 0.47 \mathrm{pmol} / \mathrm{mg}$ (group 1)). The different islet preparations used for transplantation did not differ in their islet insulin content (ranging between $6.31 \pm 0.48$ $\mathrm{pmol} / \mathrm{islet}$ (group 1) and $6.99 \pm 0.37 \mathrm{pmol} /$ islet (group 2)), and were characterized by a markedly enhanced insulin secretion in response to glucose (data not shown). The grafted untreated animals (group 1) relapsed into hyperglycaemia within $7.3 \pm 0.5$ days. The application of $1.5 \mathrm{mg}$ cyclosporin $/ \mathrm{kg}$ body weight (group 2) did not result in a significant prolongation of the mean graft survival time ( $8.8 \pm 1.0$ days) (Fig. 1$)$. Seven days after the onset of rejection, the plasma glucose was above $25 \mathrm{mmol} / \mathrm{l}$ in both groups.

Treating the recipients with $1 \mathrm{mg}$ anti-IL-2 RMAB/ $\mathrm{kg}$ body weight for 10 days (group 3 ) resulted in a significant $(42.5 \pm 15.3, p<0.01)$ prolongation of graft surviv$\mathrm{al}$, and in 3 out of 11 animals a permanent graft acceptance occured (Fig. 1). The mean non-fasting plasma glucose of the 3 long-term acceptors (weekly determination from days 42 to 119 after transplantation) was $8.92 \pm 2.41 \mathrm{mmol} / 1(\mathrm{n}=36)$. The glucose tolerance at day 40 was $1934 \pm 438 \mathrm{mmol} \cdot \mathrm{l}^{-1} \cdot \mathrm{min}^{-1}$ and at day 120 $1769 \pm 357 \mathrm{mmol} \cdot 1^{-1} \cdot \mathrm{min}^{-1}$. These animals developed marked hyperglycaemia immediatedly after graft removal. On histology the grafts were virtually free of lymphocytic infiltrations, and the B cells contained insulin as demonstrated by immunohistochemistry (data not shown).

The combined application of cyclosporin and antiIL-2Rmab (group 4) resulted in a significantly prolonged graft survival ( $45.1 \pm 14.6$ days, $p<0.01$, versus the untreated animals of group 1), and in 3 out of 11 animals a permanent graft acceptance occured (Fig.1). The 
mean non-fasting plasma glucose (determined between days 42 and 119) in these three animals was $6.18 \pm$ $0.71 \mathrm{mmol} / 1(n=36)$, and the glucose tolerance was $1142 \pm 21 \mathrm{mmol} \cdot 1^{-1} \cdot \min ^{-1}$ at day 40 and $1351 \pm 43$ $\mathrm{mmol} \cdot \mathrm{1}^{-1} \cdot \mathrm{min}^{-1}$ at day 120 (normal range \pm 2 $\left.\mathrm{SD}=1107-1571 \mathrm{mmol} \cdot 1^{-1} \cdot \mathrm{min}^{-1}\right)$. In these animals graft removal resulted in the immediate development of hyperglycaemia, since the pancreatic insulin content was still very low $(0.78 \pm 0.08 \mathrm{pmol} / \mathrm{mg})$. Graft morphology demonstrated a tissue free of infiltrating cells with well granulated pancreatic B cells as demonstrated by immunocytochemistry (data not shown).

\section{Discussion}

Since the diabetic recipients, characterized by the determination of hyperglycaemia and pancreatic insulin content, and the graft viability and function, characterized by determination of islet insulin content and insulin secretion in vitro, were identical at transplantation, the observed differences of mean survival time can only be ascribed to the different treatment of the recipient rats. In accordance with earlier studies from this laboratory [8], grafted pancreatic islets were rejected within 11 days after transplantation, indicating that the selected histocompatibility barrier could not be overcome if freshly isolated pancreatic islets were used as donor tissue, and if no immunosuppression was induced. Whereas low dose cyclosporin treatment was ineffective in preventing graft rejection, the temporary application of anti-IL$2 \mathrm{R}$ mab resulted in a prolongation of islet survival when applied alone and also when given together with low dose cyclosporin, suggesting that IL-2 expressing cells are involved in graft rejection [2]. The anti-IL-2R mab therapy may exert its effects in vivo either by blocking the IL-2 receptor $[1,4]$, thereby inhibiting the clonal expansion of the antigen-activated cells, or alternatively by eliminating the IL-2R bearing cells. Recently, it has been shown that temporary treatment of allografted heart recipients, with mab directed to the IL-2 receptor, resulted in a postponement of allograft rejection [3]. In contrast to the results observed in experimental heart transplantation, we observed under respective experimental conditions in 3 out of 11 animals a permanent pancreatic islet graft survival ( $>120$ days). The marked glucose intolerance observed in these 3 rats after transplantation of 1000 pancreatic islets (which corresponds to about $35 \%$ of total pancreatic insulin content of adult rats) led us to assume that a considerable part of the transplanted islets must have been destroyed under these conditions. The additional application of cyclosporin together with anti-IL-2Rmab resulted also in a permanent acceptance in 3 out of 11 rats. Even this combined form of therapy did not, however, prevent allograft rejection. Further studies with modified doses, treatment periods and modulated pancreatic islets [9] might lead to a further increase of graft acceptance rates.

Nevertheless, this study demonstrated that the 3 animals with long-term acceptance of the allograft after combined treatment of cyclosporin and anti-IL-2 RMAB maintained not only normoglycaemia, but also a normal glucose tolerance up to 120 days, possibly suggesting a synergistic effect of both immunomodulators. A similar synergistic effect of cyclosporin and anti-IL$2 \mathrm{Rmab}$ could also be recently observed in heart allografts [10]. In conclusion, the results demonstrated an inhibitory action of anti-IL-2R mab on graft rejection, even though the mab was only temporarily administered.

\section{References}

1. Diamantstein T, Osawa $H$ (1986) The interleukin-2 receptor, its physiology and a new approach to a selective immunosuppressive therapy by anti-interleukin- 2 receptor monoclonal antibodies. Immunol Rev 92: 5-27

2. Lord RH, Hancock WW, Colby AJ, Diamantstein T, Tilney NL (1986) Effects of anti-IL-2 receptor monoclonal antibody on IL-2 receptor positive cells infiltrating cardiac allografts in the rat. XI. International Congress Transplantation Society, Helsinki (Finland) 3.-8.8. 1986 (Abstract)

3. Kupiec-Weglinski JW, Diamantstein T, Tilney NL, Strom TB (1986) Therapy with monoclonal antibody to interleukin-2 receptor spares suppressor T-cells and prevents or reverses acute allograft rejection in rats. Proc Natl Acad Sci USA 83: 2624-2627

4. Osawa H, Diamantstein T (1984) Partial characterization of the putative rat-interleukin-2 receptor. Eur J Immunol 14: 374-376

5. Ziegler B, Hahn HJ, Ziegler M (1985) Insulin recovery in pancreas and host organs of islet grafts. Exp Clin Endocrinol 85: 53-60

6. Hahn HJ (1978) Die isolierte Langerhans'sche Insel, ein Modell zur Untersuchung der Insulinsekretion in vitro. Endokrinologie $71: 308-324$

7. Dorn A, Ziegler M, Bernstein HG, Dietz H, Rinne A (1983) Introducing a monoclonal antibody to insulin: the islets of Langerhans as a model for immunocytochemistry. Acta Histochem 73: 293-295

8. Wilke B, Reiher K, Schmidt S, Klöting I (1986) Verlängerung der Überlebenszeit im Lewis-Ratten-System durch Kultivierung oder PUVA-Vorbehandlung der isolierten Inseln. Z Exp Chir Transplant Künstl Organe 19:249-251

9. Lacy PE, Davic JM (1984) Transplantation of pancreatic islets. Ann Rev Immunol 2: 183-198

10. Diamantstein T, Volk HD, Tilney NL, Kupiec-Weglinski JW (1986) Specific immunosuppressive therapy by monoclonal antiIL-2 receptor antibody and its synergistic action with cyclosporin. Immunobiology, 172: 391-399

Received: 11 November 1986,

and in revised form: 15 November 1986

Dr. H.-J.Hahn

Institut für Diabetes

"Gerhardt Katsch"

DDR-2201 Karlsburg

German Democratic Republic 